\title{
A Numerical Modeling on Light I-V Curves of Hetero-Junction Amorphous Silicon Solar Cells
}

\author{
Hu Zhi-Hua ${ }^{1, *}, H u S h u-Y u^{2}$ \\ ${ }^{1}$ Key Lab.of Advanced Technology \& Preparation for Renewable Energy Materials, State Ministry of \\ Education, Yunnan Key Lab.of Rural Energy Engineering, School of Energy and Environmental \\ Sciences, Yunnan Normal University, Kunming, 650092, China \\ ${ }^{2}$ College of Mechanical and Electronic Engineering, China University of Petroleum, Qingdao, 266580, \\ China \\ *E-mail: 1049173841@qqq.com
}

doi: $10.20964 / 2021.08 .20$

Received: 29 March 2021 / Accepted: 11 May 2021 / Published: 30 June 2021

\begin{abstract}
In this work, AMPS-D (Analysis of Microelectronic and Photonic Structures $\square$ mode was used to simulate hetero-junction amorphous silicon solar cell. The influence of energy band mismatch at $\mathrm{p} / \mathrm{i}$ interface and Schottky barrier at TCO/p or n/metal interfaces on light I-V characteristics was investigated on a solar cell with a pin structure of TCO/p-a-SiC:H/i-a-Si:H/n-a-Si:H/metal. Simulation shows that the energy band mismatch at $\mathrm{p} / \mathrm{i}$ interface is the main cause of the abnormal bending of the light I-V curves in a voltage range of less than the open circuit voltage (Voc). Schottky barrier $E_{p}$ at $T C O / p$ or $E_{n}$ at $\mathrm{n} /$ metal interfaces causes the light I-V curve bending in a voltage range higher than Voc.
\end{abstract}

Keywords: AMPS-1D, hetero-junction, amorphous silicon, solar cell

\section{FULL TEXT}

(C) 2021 The Authors. Published by ESG (www.electrochemsci.org). This article is an open access article distributed under the terms and conditions of the Creative Commons Attribution license (http://creativecommons.org/licenses/by/4.0/). 